\title{
Biotreatment of AL-KARAMA Teaching Hospital Wastewater Using Aerobic Packed Bed
}

\author{
Alaa Kareem Mohammed" Safa Abid AL-Rassul Ali** \\ Received 4,March,2012 \\ Accepted 30,April,2012
}

\begin{abstract}
:
This study is aimed to use the aerobic packed bed in biotreatment of the wastewater which is discharge from AL-KARAMA teaching hospital in Baghdad. The performance of packed-bed treatment method was examined for elimination of the organic compounds from wastewater under aerobic conditions. In this research different parameters were studied. They were: inoculums concentration, circulation rate of wastewater through the bed, packing type and the temperature. Results showed that the system efficiently removed about $82 \%$ of the chemical oxygen demand (COD) and $80 \%$ of the Biological oxygen demand (BOD). Percent reduction in turbidity was about $92 \%$ and reduction in nitrate concentration was about $87 \%$. It was found that best performance of the packed bed method was obtained at temperature of $37^{\circ} \mathrm{C}$, circulation rate of $10 \mathrm{~L} / \mathrm{min}$ and inoculums concentration of $3 \%$.
\end{abstract}

\section{Key words: Packed bed, wastewater treatment, BOD, COD}

\section{Introduction:}

The hospital wastewater contains various types of potentially hazardous and toxic materials, such as microbial pathogens, chemicals, disinfectants and pharmaceuticals [1]. The discharged wastewater from the hospital requires proper processing system in order to limit negative impacts on the environment and outside hospitals. These chemical compounds can provoke the pollution of the natural environment by entailing a biological imbalance. So it seems important to consider upstream treatments to hospital wastewater before their discharge in the municipal sewage system. Biological treatment methods have traditionally been used for the management of pharmaceutical wastewater. They may be subdivided into aerobic and anaerobic processes [2]. Aerobic applications include activated sludge, membrane batch reactors and sequence batch reactors. Anaerobic methods include anaerobic sludge reactors, anaerobic film reactors and anaerobic filters. A number of pilot scale studies have been conducted using Sequence batch reactors (SBRs) and Membrane bioreactors (MBRs) in an attempt to improve the effectiveness of treatment. [3,4]. The wastewater characteristics play a key role in the selection of biological treatment method. Presence of solvents activated pharmaceutical ingredients (APIs), intermediates and raw materials represent biologically recalcitrant substances, so a suitable treatment method should be chosen that gives efficient biological treatment. $[5,6]$. Packed bed is a bed in which a fixed packing (support medium) provides an attachment surface that supports the aerobic microorganisms in the form of a biofilm. Treatment occurs as wastewater flows upwards through this bed and dissolved pollutants are absorbed by biofilm. Various types of packing can be used, such as Ceramic

\footnotetext{
* Genetic Engineering and Biotechnology Institute for Postgraduate Studies /Baghdad University, Baghdad, Iraq

** Genetic Engineering and Biotechnology Institute for Postgraduate Studies /Baghdad University, Raohdad Iran 
rings, glass beads, polypropylene mesh......etc.

The purpose of this research was to study the performance of packed bed system in removal of pollutants from AL-KARAMA teaching hospital wastewater under several operating conditions such as inoculums concentration, wastewater circulation rate, bed temperature and packing type.

\section{Material and Methods:}

\section{Packed bed system:}

The packed bed system was installed in the institute of Genetic engineering and Biotechnology / University of Baghdad. The system was operated at a rate of 40L/day of AL-KARAMA Teaching hospital wastewater. Fig.(1 ) shows a schematic diagram of the packed bed reactor, which is constructed of 10" polyethylene cylinder of $25 \mathrm{~cm}$ diameter and $150 \mathrm{~cm}$ high. The bed is fitted with a sampling point. Feed streams into the bed are air and wastewater .The air stream is uniformly bubbled in the liquid phase via perforated tube to provide oxygen for microorganisms and to create a mixed wastewater, while the feed wastewater is pumped to the top part of the bed and distributed through the packing. As a result, gas bubbles coales and escape through the top of the bed, while the liquid flows toward the bottom of the bed. Microorganisms in the aerated packed bed grow and degrade organic matter contained in the wastewater. After several circulations of liquid product through the bed, the liquid exit from the bottom of the bed through a bottom port. The feed wastewater is kept in the feed tank which is fitted with an immersion heater to maintain constant temperature through the experiment. Also another immersion heater is positioned in the top of the bed to ensure temperature uniformity. Flow rate of liquid through the bed is controlled by the use of a variable speed Watson Marlo pump.

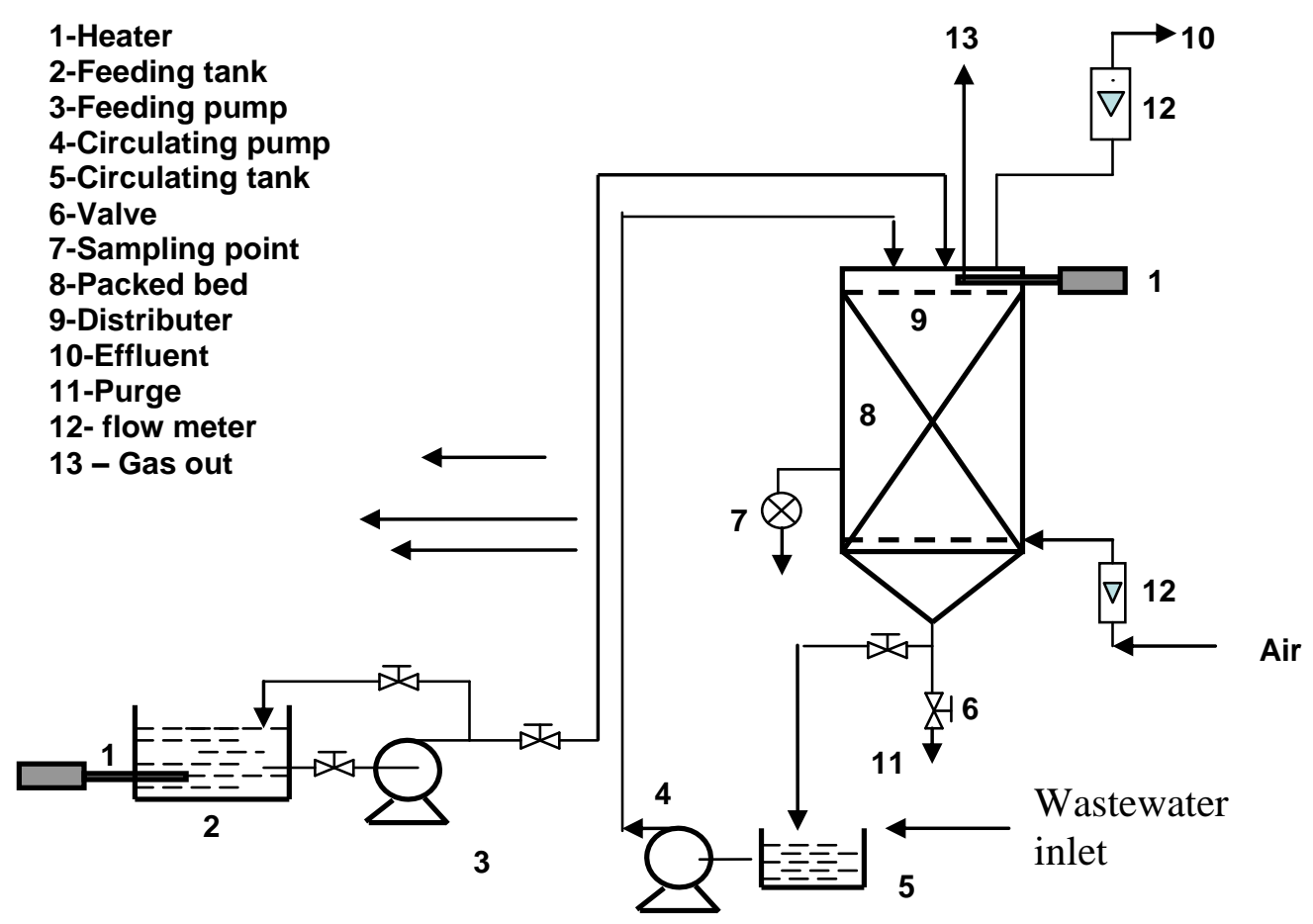

Fig. (1): Schematic diagram of the packed bed system. 


\section{Collection of samples:}

Sterile $500 \mathrm{ml}$ glass bottles were used to collect effluent sample from the system of treatment. Samples were collected every five hours during the study period. Duplicate samples were collected and stored in a refrigerator. After collection all the samples were processed.

\section{Analytical Instruments}

Operation of packed bed required preparation of the wastewater feed. The wastewater was prepared and mixed in the feed tank with inoculums of isolate Klebsiella pneumonia (previously isolated from the hospital wastewater and diagnosed in the institute of Genetic engineering and Biotechnology / University of Baghdad). Part of this wastewater was pumped through the system to fill the bed. During the initial preparation period temperatures of both immersion heaters were adjusted and kept constant to reach steady state conditions. Then followed by adjustment of the air feed flow rate. Finally, nutrients, $(\mathrm{NaCl}-8 \mathrm{gm} / \mathrm{L}$, $\mathrm{K}_{2} \mathrm{HPO}_{4}-1.21 \mathrm{gm} / \mathrm{L}, \quad \mathrm{KH}_{2} \mathrm{PO}_{4}-0.34$ $\mathrm{gm} / \mathrm{L}$ with $\mathrm{pH} 7.3$ ), were added to sustain proper growth of microorganism cells. Experimental measurement starts with addition of the wastewater through the top of the bed, where cells are attached to the packing by covalent bonding. A period of time (4-10 hr) is allowed for complete contact and bonding before flow of fresh medium is started [7]. After that the feed pump is operated and flow through the bed is allowed to circulate several times, and then exit the bed via bottom opening. Liquid samples are taken at constant time interval from the sampling point in the bed. COD, BOD, turbidity, $\mathrm{NH}_{4}-\mathrm{N}$ and $\mathrm{pH}$ were measured in accordance with the standard methods [8]. The operating parameters throughout the experiments were:

Air flow was fixed at $120 \mathrm{~L} / \mathrm{hr}$.

Total hold up was 25 lit

Liquid circulation rate: $2-10 \mathrm{~L} / \mathrm{min}$

Temperatures: $25,37,45{ }^{\circ} \mathrm{C}$

\section{Result and discussion:}

Many wastewater samples were collected from AL-KARAMA Teaching hospital main sewage during summer season (Jun, July and August). The average characteristics of the wastewater are presented in Table (1).

Table (1): Characteristics of wastewater from AL-KARAMA Teaching hospital.

\begin{tabular}{|l|l|}
\hline Item & Measured value \\
\hline COD & $470-490$ \\
\hline BOD $_{5}(\mathrm{mg} / \mathrm{L})$ & $270-285$ \\
\hline $\mathrm{NH}_{4+-\mathrm{N}}(\mathrm{mg} / \mathrm{L})$ & $15-20$ \\
\hline Turbidity (NTU) & $80-100$ \\
\hline $\mathrm{pH}$ & $6-8$ \\
\hline
\end{tabular}

The following analysis focuses on the parameters studied in this analysis which were; inoculums concentration, wastewater circulation rate, bed temperature and packing type.

\section{Effect of inoculums Concentration}

Three values of inoculums concentration of isolate Klebsiella pneumonia (previously isolated and diagnosed) were used in this study. These values were $1 \%, 2 \%$ and $3 \%$. Fig. (2) shows that the values of BOD are decreased with increasing the concentration of inoculums. This behavior is caused by the higher growth rate of microorganisms at high values of inoculums concentrations which lead to higher rate of organic matters degradation in wastewater. This finding is in agreement with that reported by Madukasi [9]. 


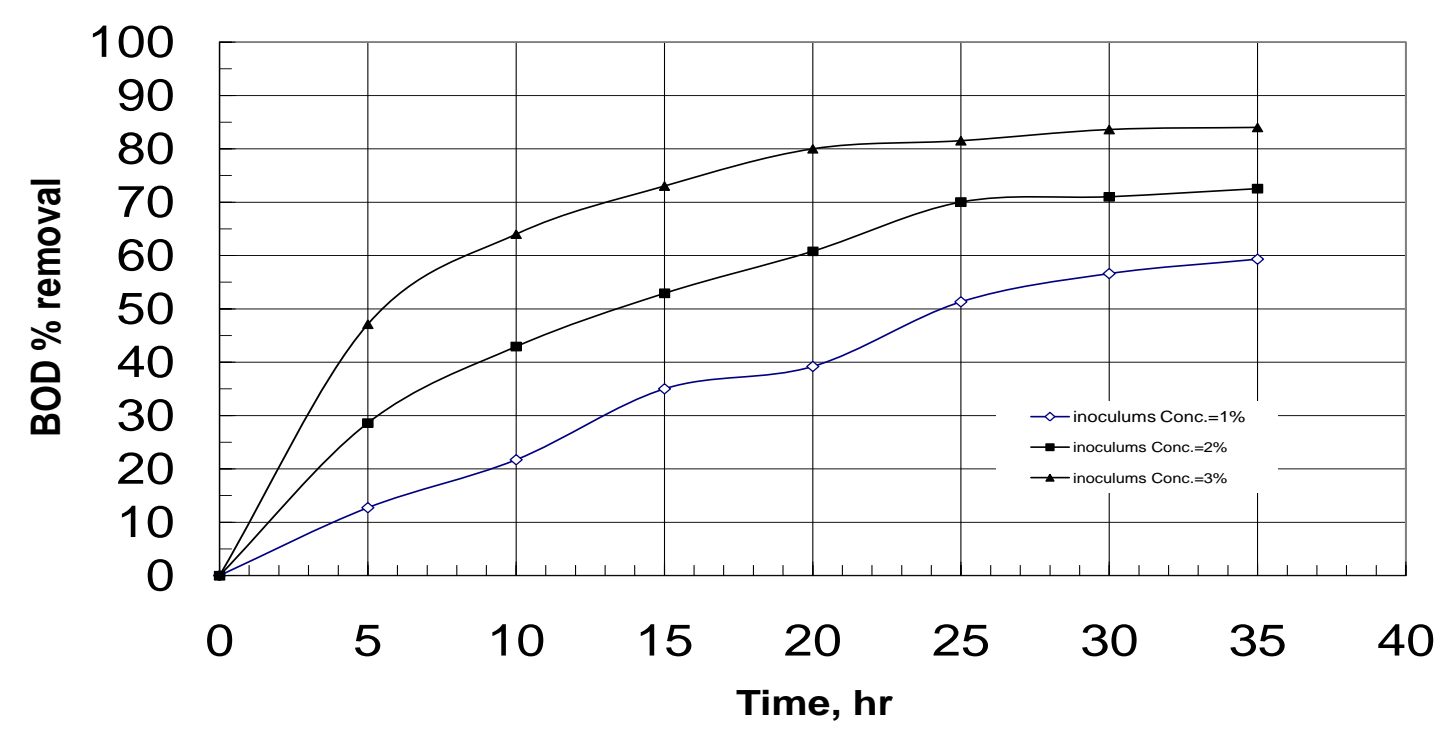

Fig. (2); Effect of inoculums concentration on BOD removal. (Circulation rate $=10 \mathrm{~L} / \mathrm{min}$., $\mathrm{T}=37^{\circ} \mathrm{C}$, packing is Polypropylene mesh, 20 mesh.)

\section{Effect of circulation rate}

Three values of circulation rates were tested; 4, 6, 10 L/min. Fig.(3) shows that the rate of decreasing COD is higher when circulation rate is increased. Circulation rate of $10 \mathrm{~L} / \mathrm{min}$. gave higher removal of COD. Turbidity of wastewater was also studied at different circulation rates. Fig.(4) shows that using circulating rate of $10 \mathrm{~L} / \mathrm{min}$ results in about $92 \%$ removal of turbidity. Oktem[10]. reported that increasing circulation rate leads to decreasing in turbidity. Also Fig. (5) shows $85 \%$ removal of nitrate concentration occurs at $10 \mathrm{~L} / \mathrm{min}$ circulation rate the point which in agreement with that mentioned by Suarez [11]. This behavior can be interpreted as high circulation rate leads to high turbulence within the circulating eddies of the liquid and increase in rate of aeration and growth of microorganisms. So more broth organic is degraded.

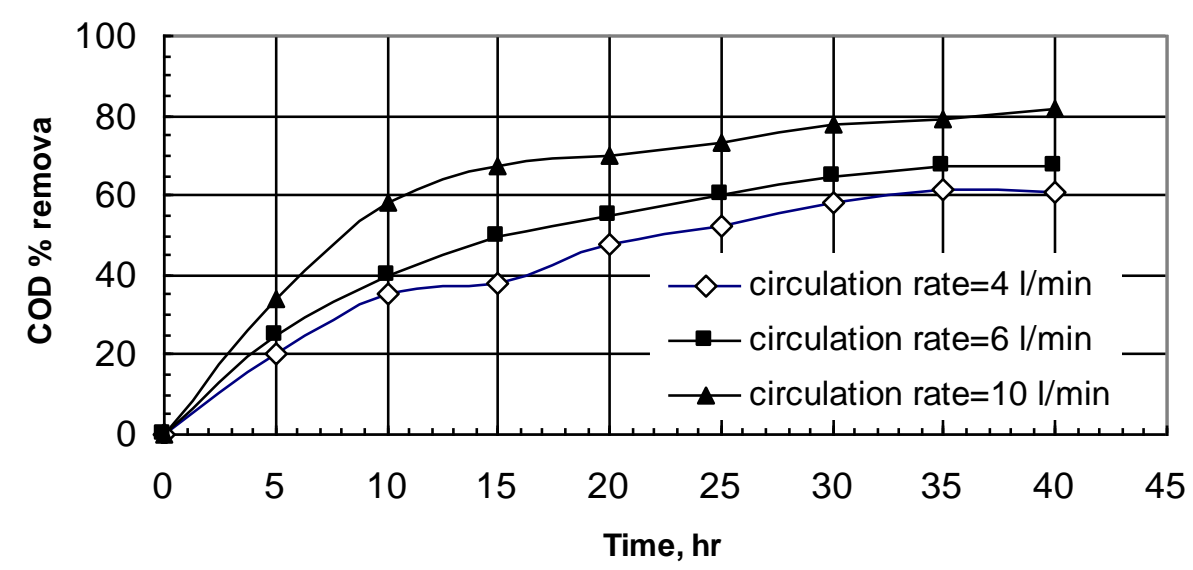

Fig.(3): Effect of circulation rate on COD removal. (Inoculums conc. $=3 \%, \mathrm{~T}=37^{\circ} \mathrm{C}$, Packing is Polypropylene mesh, 20 mesh.) 


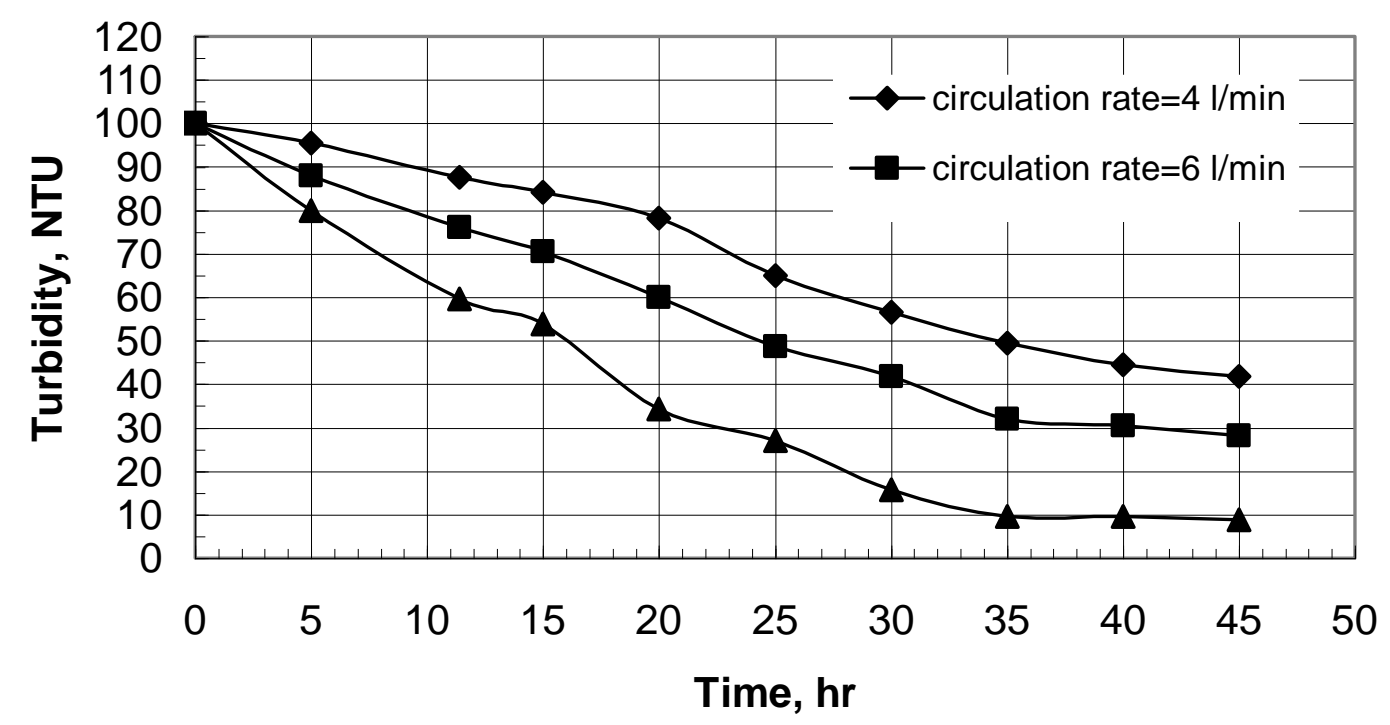

Fig. (4): Effect of circulation rate on turbidity of wastewater. (Inoculums conc. $=3 \%$ $\mathrm{T}=37^{\circ} \mathrm{C}$, packing is Polypropylene mesh, 20 mesh.)

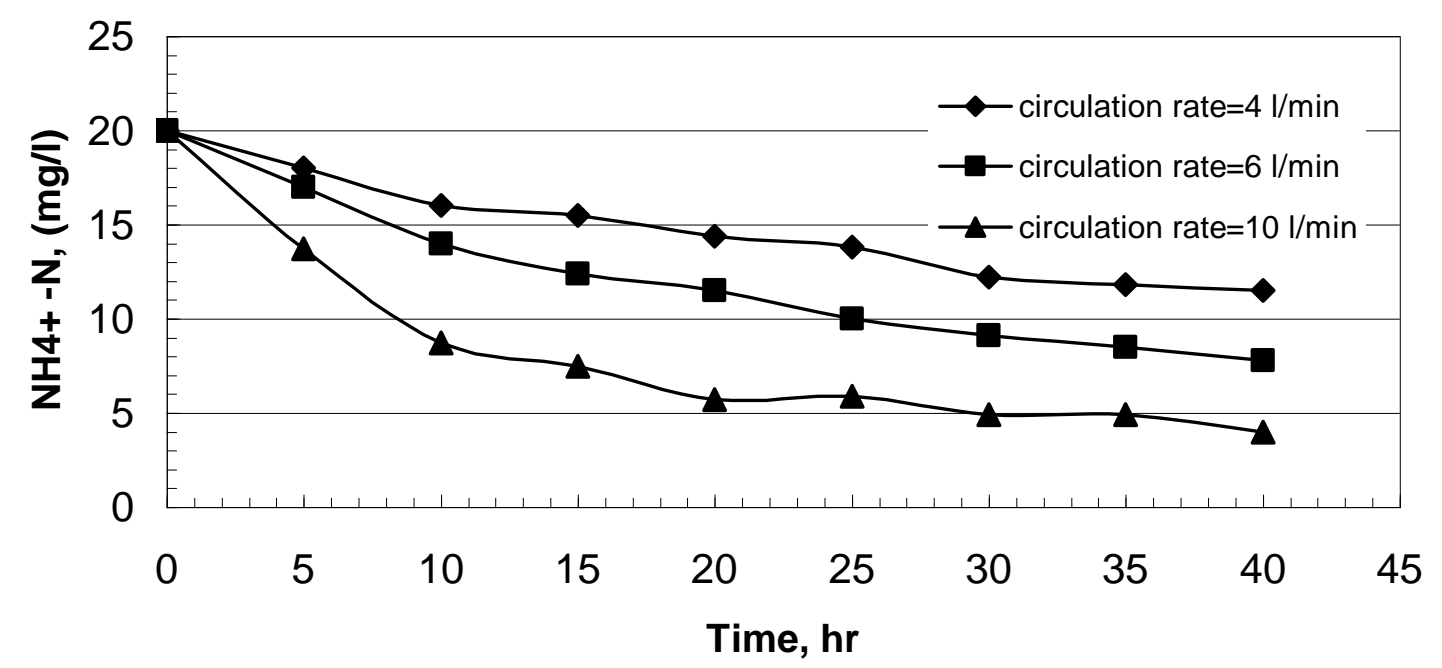

Fig(5) : Effect of circulation rate on Nitrate concentration. (Inoculums conc. $=3 \%$ $\mathrm{T}=37^{\circ} \mathrm{C}$, packing is Polypropylene mesh, 20 mesh.)

\section{Effect of temperature}

Fig. (6) shows the effect of temperature upon the action of the microorganisms in degradation of organic matters in the wastewater. The results show that the removal efficiency of BOD is increased as the temperature increases from $25^{\circ} \mathrm{C}$ to $37^{\circ} \mathrm{C}$ but it decrease when the temperature is increased to $45^{\circ} \mathrm{C}$. This is may be due to the effect of temperature on the activity of the microorganisms. Since at temperatures above $\quad 40^{\circ} \mathrm{C}$, the membrane compositions of microorganisms are affected, e.g. the phospholipids fatty acid composition changes with temperature and hence affects the enzymatic system of the bacteria. This leads in turn to decreasing the removal of BOD. So the best operating temperature is about $37^{\circ} \mathrm{C}$. This result is agreed with the results reported by Dalrymple [12] who reported that $37^{\circ} \mathrm{C}$ is the best temperature for treatment. 


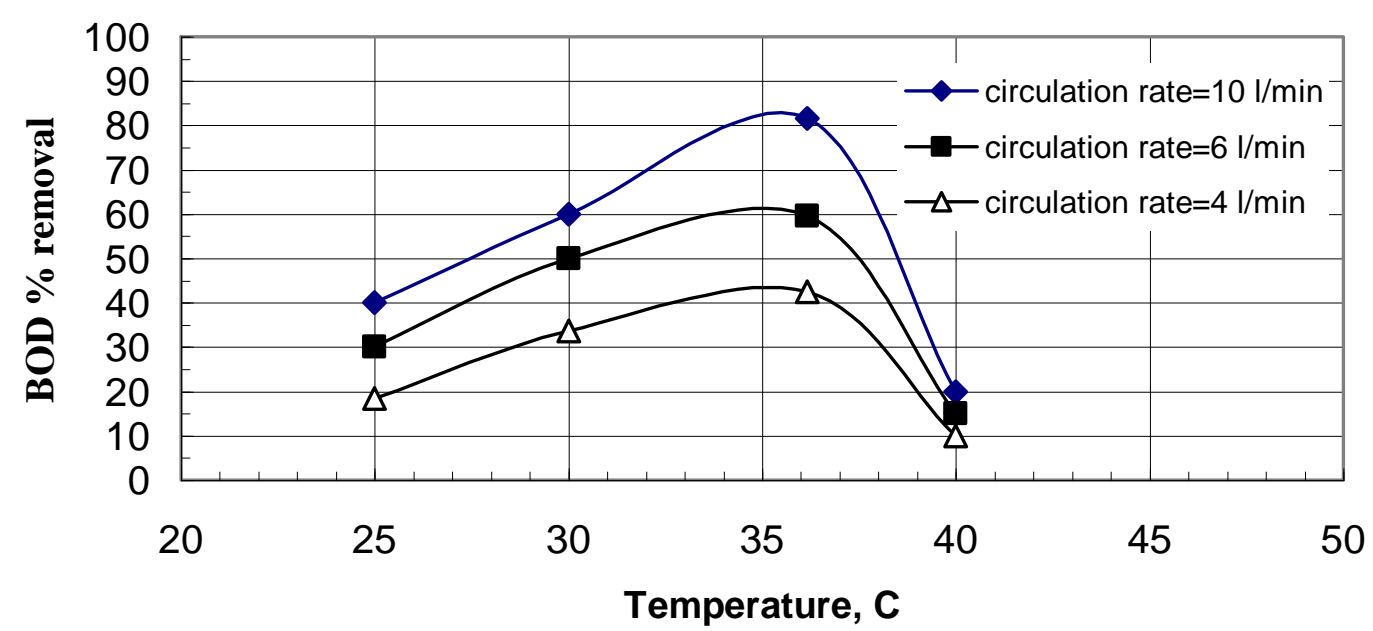

Fig.(6); Effect Temperature on BOD removal. (Time $=35 \mathrm{hr}$, Inoculums conc. $=3 \%$, Circulation rate $=10 \mathrm{~L} / \mathrm{min}$., packing is Polypropylene mesh, $20 \mathrm{mesh}$.).

\section{Effect of Packing Type}

Three types of packing were used in this study. They are; 1- Polypropylene mesh (20 mesh). 2- Ceramic rashig ring $(1 / 4 \mathrm{in})$. 3 -glass beads $(1 \mathrm{~cm})$. Fig.(7) shows that packing type of polypropylene mesh gives most decrease in value of COD about $83 \%$, while glass beads give the lowest value of percent removal $(55 \%)$. That is because the packing which provide adequate interstitial space for cell entrapment, such as mesh packing, result in faster biomass loading rates. Also the roughness of the packing is a factor as noted in the comparison of the glass and ceramic rashig rings. Although all packing surface were coated with gelatin to assure a monolayer of cells, polypropylene mesh enable a better coating and provided spaces for subsequent layers of the cell to accumulate [13].

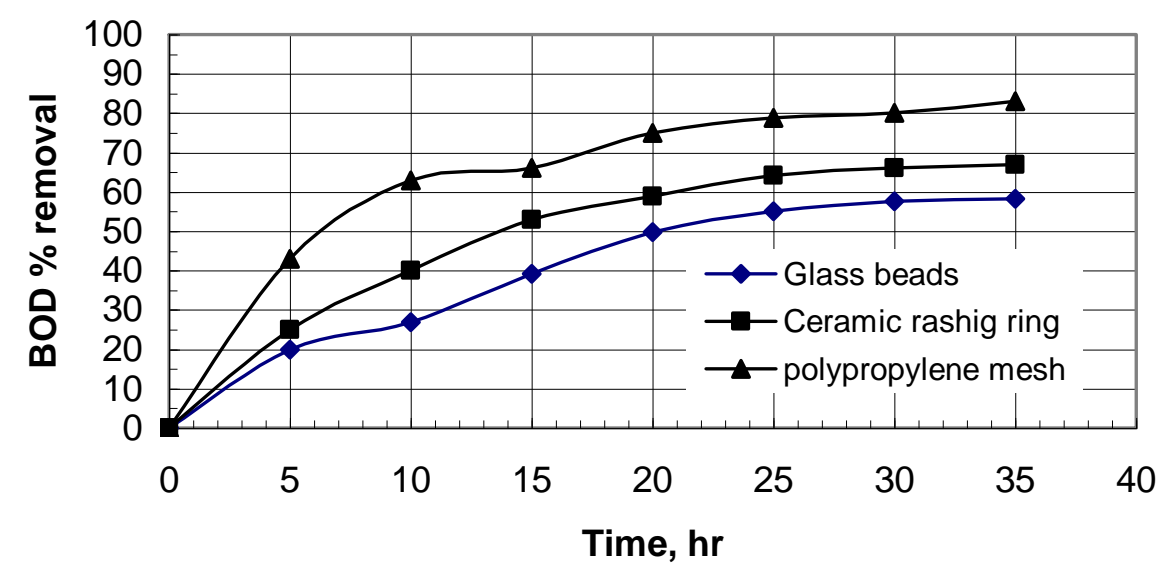

Fig(7): Effect of packing type on BOD removal. (Inoculums conc. $=3 \%$, circulation rate $=10 \mathrm{~L} / \mathrm{min}$., $\mathrm{T}=37{ }^{\circ} \mathrm{C}$.)

\section{Conclusions:}

1- The removal efficiency of BOD is increased as the concentration of isolate inoculums of Klebsiella pneumonia increased. Concentration of inoculums of $3 \%$ gives the best result. Also BOD removal efficiency is increased as 
the circulation rate of wastewater through the bed increased. Optimum BOD removal efficiency occurs at about $37^{\circ} \mathrm{C}$.

2- Packing type of Polypropylene mesh (20 mesh) gives highest value of BOD removal efficiency which reaches to about $83 \%$.

3- Turbidity and Nitrate concentration are reduced with increasing circulation rate. The best circulation rate through the bed is $10 \mathrm{~L} / \mathrm{min}$.

\section{References:}

1- Castiglioni, S.; Bagnati, R. and Fanelli, R., 2006. Removal of Pharmaceuticals in Sewage by treatment Plants in Italy. Environ. Sci. Tech., 40 (1), 357-363.

2- Gangagni Rao, A.; Venkata Naidu, G. And Krishna Prasad, K., 2005 Anaerobic treatment of wastewater with high suspended solids from a bulk drug industry using fixed film reactor (AFFR). Bioresour. Tech., 96(1), 8793.

3- Jones, O.; Voulvoulis, N.; Lester, J., 2007 The occurrence and removal of selected pharmaceutical compounds in a sewage treatment works utilizing activated sludge treatment. Environ. Pollut., 145 (3), 738-744.

4- Carballa, M.; Fink, G. and Omil, F., 2008. Determination of the solid-water distribution coefficient $(\mathrm{Kd})$ for pharmaceuticals, estrogens and musk fragrances in digested sludge. Water Res., 42, (1-2) 287-295.

5- Yuan, F.; Hu, C.; Hu, X.; Qu, J.; Yang, M., 2009 Degradation of selected pharmaceuticals in aqueous solution with $\mathrm{UV}$ and $\mathrm{UV} / \mathrm{H}_{2} \mathrm{O}_{2}$. Water Res., 43 (6), 1766-1774.

6- Chang, C.; Chang, J.; Vigneswaran, S.; Kandasamy, J., 2008 Pharmaceutical wastewater treatment by membrane bioreactor process- a case study in southern Taiwan. Desalination, 234 (1-3), 386-392.
7- El Gohary, F.; Abou-Elea, S., 1995 Evaluation of biological technologies for wastewater treatment in the pharmaceutical industry. Water Sci. Tech., 32(11), 13-20.

8- Radjenovic, J.; Petrovic, M.; Barcelo, D., 2007 Analysis of pharmaceuticals in wastewater and removal using a membrane bioreactor. Anal. Bioanal. Chem., 387 (4), 1365-1377.

9- Madukasi, E. I. and Zhou, J., 2012 Potentials of phototrophic bacteria in treating pharmaceutical wastewater. Int. J. Environ. Sci. Tech., 7 (1), 165174.

10- Oktem, Y.; Ince, O. and Sallis, P., 2007. Anaerobic treatment of a chemical synthesis-based pharmaceutical wastewater in a hybrid upflow anaerobic sludge blanket reactor. Bioresour. Tech., 99 (5), 10891096.

11- Suarez, S.; Lema, J.; Omil, F., 2009 Pre-treatment of hospital wastewater by coagulation-flocculation and flotation. Bioresour. Tech., 100 (7), 2138-2146.

12- Dalrymple, O.; Yeh, D. and Trotz, M., 2007. Removing pharmaceuticals and endocrine-disrupting compounds from wastewater by photocatalysis. J. Chem. Tech. Biotech., 82 (2), 121-134. 13- Chitnisa,V.,S. and Vaidyaa, S., 2004 Bacterial population changes in hospital effluent treatment plant. Wat. Sci. Technol., 35: 1-12 
المعالجة الحيوية الهوائية لمياه صرف المستثفى باستخدام عمود محثو

صفاء عبد الرسول علي*

علاء كريم محمد

*معهد الهنسة الور اثية و التقنيات الاحيائية للار اسات العليا/ جامعة بغداد

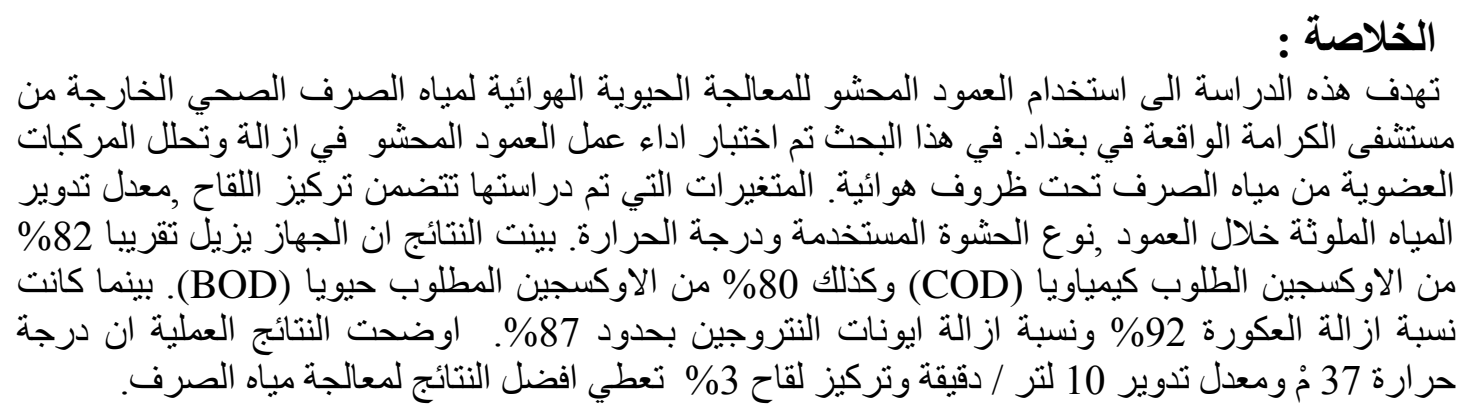

